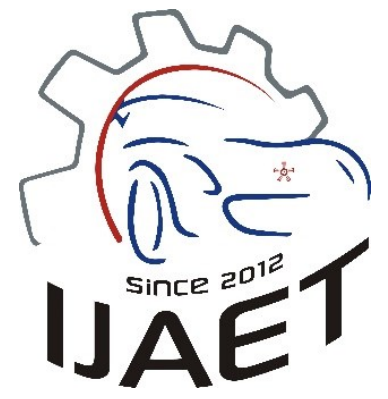

e-ISSN: 2146 - 9067

International Journal of Automotive

Engineering and Technologies

journal homepage:

https://dergipark.org.tr/en/pub/ijaet

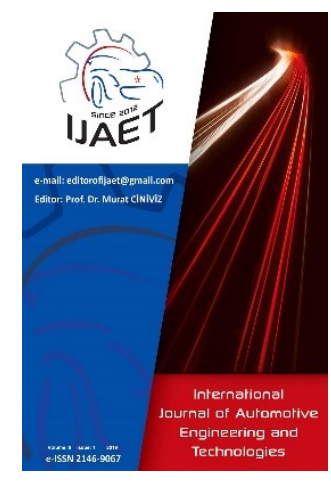

Original Research Article

\title{
Evaluation of glycerol tert-butyl ethers as renewable fuel JournalPark additive
}

\author{
Abdülvahap Çakmak ${ }^{1}$,, Hakan Özcan² \\ ${ }^{1}$ Samsun University, Kavak Vocational School, Department of Motor Vehicles and Transportation Technologies, Samsun, Turkey. \\ ${ }^{2}$ Ondokuz Mayıs University, Faculty of Engineering, Department of Mechanical Engineering, Samsun, Turkey.
}

\section{ARTICLE INFO}

${ }^{1} 0000-0003-1434-6697$

${ }^{2} 0000-0002-7848-3650$

* Corresponding author

abdulvahap.cakmak@samsun.edu.tr

Received: Oct 15, 2019

Accepted: Fab 26, 2020

Published by Editorial Board Members of IJAET

(C) This article is distributed by Turk Journal Park System under the CC 4.0 terms and conditions.

\begin{abstract}
The aim of this research is the investigation of using glycerol tert-butyl ethers as a bio-renewable fuel additive to diesel-biodiesel blend in a diesel engine. In this context, an experimental study was carried out to synthesize glycerol tert-butyl ethers and investigate the effect of glycerol ethers on diesel engine performance and emissions. Glycerol tert-butyl ethers were synthesized by the etherification reaction of glycerol with tert-butyl alcohol (TBA) in a high-pressure stainless steel batch reactor using Amberlyst-15 as solid acidic catalyst. Produced glycerol ethers were mixed by 2 vol.\% with a biodiesel-diesel blend to investigate the glycerol ethers usage as a fuel additive in a diesel engine. Three test fuels were considered for the experiments: (i) diesel fuel, (ii) B20 (80 vol.\% diesel +20 vol.\% corn oil biodiesel); (iii) BD+GTBEs ( 80 vol. \% diesel + 18 vol.\% corn oil biodiesel +2 vol. $\%$ glycerol tert-butyl ethers). Some basic fuel properties of test fuels were determined prior to engine tests. Engine performance and emissions tests were performed on a single-cylinder research diesel engine at four brake power output. The results revealed that the addition of glycerol tert-butyl ethers in the fuel showed no significant effect on determined fuel properties and caused a decrease in engine performance and exhaust emissions except for $\mathrm{CO}$ emissions when compared to base diesel fuel. However, BD+GTBEs presented similar performance and emissions characteristics with B20, as a consequence, glycerol tert-butyl ethers have the possibility of being utilized as a bio-renewable fuel additive to diesel-biodiesel blends.

Keywords: Glycerol tert-butyl ethers, Oxygenated fuels, Biodiesel, Diesel engine, Performance, Emissions
\end{abstract}

\section{Introduction}

Global energy demand increases continuously and the growth in energy demand comes from fast-growing industrialization and population. Today, the world's energy supply is heavily dependent on nonrenewable natural energy sources like coal, natural gas, and petroleum. But, the limited reserves of fossil resources, an increase in oil prices, and environmental problems have led to an interest in alternative energy sources that are renewable and environment-friendly.

The transportation sector that mainly uses internal combustion engines as a power source currently consumes about $21 \%$ of global energy [1]. However, the transport sector continues to 
be dominated by petroleum products despite increasing the share of alternative fuels. For this reasons, policies are enforced to further increase the use of biofuels in transport and it is planned to increase the share of biofuels in road transport in the OECD (the Organization for Economic Co-operation and Development) countries to $20 \%$ and to $10 \%$ in the rest of the world by 2040 [1].

Biodiesel is one of the best substitute fuels for diesel engine applications since it has many advantages over petroleum-based diesel fuel. Biodiesel is a renewable fuel produced from vegetable oils, animal fats or waste oils by the transesterification reaction. It is a biodegradable, non-toxic fuel and it contains no sulfur and aromatic compounds in its composition [2]. Without any structural modification in a diesel engine, biodiesel can be used with any desired blending ratio with diesel fuel, or as a pure fuel. Biodiesel has a higher flash point than diesel fuel, which makes it safer for transport, storage, and distribution [3]. Due to oxygen in molecular structure, it improves the fuel oxidation rate and thus lowers exhaust emissions and increases combustion efficiency. In addition, it has a high cetane number and good lubricity property [2]. Thanks to the above-mentioned advantages of biodiesel, it has emerged an alternative for petroleum-based diesel fuel and it has gained significant attention for three decades. Therefore, countries around the world have been using biodiesel produced different feedstock. Moreover, in order to reduce dependence on limited petroleum reserves, the blending ratio of biodiesel is being progressively increased. For example, the European Parliament proposed on 17 January 2018 to reach $12 \%$ renewable energy in transport fuel by 2030 [4]. In Turkey, biodiesel produced from local sources can be mixed up to 7 vol.\% with diesel fuel. Because biodiesel is a leading solution for diesel engine applications, its production experienced sustainable growth over two decades. Since 2000-2017 global biodiesel production has increased from 0.78 billion liters to 32.6 billion liters that lead to an increase in biodiesel production about forty-fold over seventeen years [5]. Additionally, it is estimated that biodiesel production can reach up to 39 billion liters in 2027 [6].

The transesterification of triglycerides results in approximately $90 \mathrm{wt} . \%$ of fatty acid esters and glycerol [7]. In other words, in the biodiesel production process, glycerol occurs as a byproduct of approximately $10 \mathrm{wt} . \%$ of produced biodiesel $[8,9]$. As a result of the increase in biodiesel production, also the production of glycerol will grow proportionally. The major problem associated with increasing biodiesel production is the surplus glycerol which could not be completely used in glycerol related industries. This can result in uncontrollable disposal of excess glycerol into the environment and could lead to serious environmental hazards [10]. Besides, it is necessary to convert excess glycerol into value-added products for sustainable and economic biodiesel production. So, the key challenge emerged is the evaluation of excess glycerol. Glycerol cannot be added directly to fuel because glycerol has inappropriate fuel properties such as high viscosity, high boiling point and immiscible with diesel fuel. However, it is demonstrated that excess glycerol can be transformed into oxygenated fuels that could be used in conventional internal combustion engines [11, 12].

Etherification of glycerol with tert-butyl alcohol (TBA) or iso-butene has emerged the most effective route to convert excess glycerol into oxygenated fuel additives. The etherification of glycerol yields mono-ethers, di-ethers, and triether of glycerol which considered as a potential oxygenated fuel additive [12, 13]. High glycerol ethers (di- and tri- glycerol ethers) are soluble in diesel and biodiesel, improving fuel properties [11] and hence high ethers are desired products. Mono- glycerol ethers have a low solubility in diesel fuel and therefore the etherification of glycerol is directed to the maximum formation on di-and tri-glycerol ethers [14, 15]. Glycerol ethers have a significant effect in decreasing the could point temperature and viscosity of neat biodiesel. It has been shown that 20 wt.\% the blend of ethers of glycerol with methyl esters results in a $5{ }^{\circ} \mathrm{C}$ reduction in cloud point temperature and an $8 \%$ reduction in kinematic viscosity [7]. Since glycerol ethers are partlyoxygenated fuels they diminish hydrocarbon emissions and particulate matter emissions [16, 17]. In addition, glycerol tert-butyl ethers are the biomass-derived product, indicating the potential of these ethers as bio additive to fuels 
[18].

Although there are many studies deal with reaction kinetics of glycerol etherification [19 28], only a few studies related to the effect of glycerol ethers on engine performance and emissions are found in the existing literature $[16,17,29,30]$ and these studies have been performed by blending ethers of glycerol with petroleum diesel. The objective of this research is to investigate the effects of glycerol ethers on performance and emissions of a diesel engine fueled with a diesel-biodiesel blend and comparing obtained results with diesel and B20 fuel. The novelty of this study is mixing produced glycerol ethers with biodiesel. Because blending glycerol ethers with biodiesel could be a practical application in the biodiesel industry.

\section{Materials and Methods}

Since glycerol tert-butyl ethers are not commercially available, enough amount of glycerol ethers were synthesized to utilize in experiments. Glycerol tert-butyl ethers were synthesized by the etherification reaction of glycerol with tert-butyl alcohol (TBA) at the presence of Amberlyst-15 as a solid acidic catalyst. In order to synthesis glycerol tert-butyl ethers, a high-pressure stainless steel batch reactor with a volume of $500 \mathrm{~cm}^{3}$ and a wall thickness of $4 \mathrm{~mm}$ was designed and manufactured. Glycerol (purity $\geq 99 \%$, TEKKİM), tert-butyl alcohol (purity $\geq 99.5 \%$, Merck) and Amberlyst-15 (dry form, Dow Chemical Company) were the basic chemicals for synthesis glycerol tert-butyl ethers. The etherification reaction conditions such as tertbutyl alcohol/glycerol molar ratio, amount of catalyst, reaction time, reaction temperature and stirring speed, which gives high glycerol conversion and high ether selectivity were determined from the previously published studies [20, 22, 23, 28, 31]. The etherification reaction conditions selected for this study are below:

- $\quad$ TBA/Glycerol molar ratio: 4:1

- Amount of Amberlyst-15: 7.5 wt.\% / glycerol

- $\quad$ Reaction temperature: $90^{\circ} \mathrm{C}$

- $\quad$ Reaction time: $3 \mathrm{~h}$

- $\quad$ Stirring speed: $1200 \mathrm{rpm}$

The reaction procedure was the following: a defined amount of glycerol, TBA and Amberlyst-15 were loaded into the reactor and the reactor was flushed with nitrogen gas to obtain an inert atmosphere. Then, the reactor was heated up to reaction temperature and the reaction started immediately by running the magnetic stirring. Reactor pressure and temperature were observed throughout the reaction. At the end of the reaction, the reactor was put into a cold water bath to reduce the reactor internal pressure and to condense all gaseous compounds into the liquid phase. The Amberlyst-15 catalyst was removed from the products by the vacuum filtration device. In order to purify the products, a two-stage distillation process was carried out. Sufficient amounts of glycerol tert-butyl ethers were produced with the same method by repeating experiments.

Glycerol is a byproduct of biodiesel production and one mole of glycerol is produced for every three moles of methyl esters. Produced glycerol is equivalent to approximately $10 \% \mathrm{wt}$. of the total product [32]. If all glycerol obtained from biodiesel production were incorporated into glycerol ethers synthesis, a roughly blending ratio of $10 \%$ would occur [33]. Therefore, a blending ratio of 10 vol.\% was chosen in this study. This blending ratio does not alter fuel characteristics greatly and it contributes to sustainable and economic biodiesel production. Produced glycerol ethers were blended with corn oil biodiesel in 10 vol.\% and this resulted in a biodiesel-glycerol ether mixture (10 vol.\% glycerol ethers +90 vol. $\%$ corn oil biodiesel). Firstly, this blend was mixed with a magnetic stirrer and then, to further increase blend homogeneity an ultrasonic mixing process was applied at $40 \mathrm{kHz}$ for the time duration of 15 min. After that, the glycerol ethers-biodiesel blend was mixed with diesel fuel in the concentration of $20 \mathrm{vol} . \%$ and this blended fuel designated as BD+GTBEs. At the final stage, BD+GTBEs was obtained with the 20 vol. $\%$ renewable fraction, containing 80 vol. $\%$ diesel fuel, 18 vol.\% biodiesel and 2 vol. $\%$ glycerol tert-butyl ethers. The other test fuel is B20 that was prepared by adding corn oil biodiesel into diesel fuel (20 vol. \% corn oil biodiesel +80 vol.\% diesel). Method of corn oil biodiesel production and basic fuel properties of produced biodiesel have been fully described elsewhere 
Table 1. The Properties of Diesel, B20, and BD+GTBEs

\begin{tabular}{llcccc}
\hline Property & Test method & Unit & D & B20 & BD+GTBEs \\
\hline Density@15 ${ }^{\circ} \mathrm{C}$ & TS EN ISO 12185 & $\mathrm{kg} / \mathrm{m}^{3}$ & 836.3 & 847.9 & 846.0 \\
Cloud point & TS 2834 EN 23015 & ${ }^{\circ} \mathrm{C}$ & -6 & -4 & -4 \\
Cold filter plugging point (CFPP) $)$ & TS EN ISO 116 & ${ }^{\circ} \mathrm{C}$ & -19 & -14 & -14 \\
Cetane index & TS EN ISO 4264 & - & 53.3 & 52 & 52.5 \\
Distillation Temperature & TS EN ISO 3405 & T10 $\left({ }^{\circ} \mathrm{C}\right)$ & 210 & 217 & 204 \\
& & T50 $\left({ }^{\circ} \mathrm{C}\right)$ & 275 & 294 & 302 \\
& & T90 $\left({ }^{\circ} \mathrm{C}\right)$ & 340 & 343 & 342 \\
\hline
\end{tabular}

Table 2. Specifications of the Test Engine

\begin{tabular}{lc}
\hline Make and Model & Kirloskar, 4-stroke, Single Cylinder Diesel Engine \\
\hline Bore/stoke, mm & $87.5 / 110$ \\
Connecting rod length, mm & 234 \\
Stroke volume, $\mathrm{cm}^{3}$ & 661 \\
Compression ratio & $17.5: 1$ \\
Rated speed, rpm & 1500 \\
Rated power, kW & 3.5 \\
Fuel injection system & Direct injection \\
Fuel pump & In line with a mechanical governor \\
Injection pressure, bar & 200 \\
Injection timing & 23 CA bTDC \\
Cooling system & Water-cooled \\
Lubricating oil & $20 \mathrm{~W}-40$ \\
\hline
\end{tabular}

Table 3. Technical Specifications of Exhaust Gas Analyzer

\begin{tabular}{lccc}
\hline Emissions & Measuring Range & Resolution & Accuracy \\
\hline $\mathrm{CO}$ & $0-10 \% \mathrm{vol}$. & $0.01 \%$ & $\pm 3 \%$ \\
$\mathrm{HC}$ & $0-5000 \mathrm{ppm}$ & $1 \mathrm{ppm}$ & $\pm 8 \mathrm{ppm}$ \\
$\mathrm{NOx}$ & $0-5000 \mathrm{ppm}$ & $1 \mathrm{ppm}$ & $\pm 25 \mathrm{ppm}$ \\
\hline
\end{tabular}

[34]. Neat diesel fuel (D) was used as a reference fuel for comparison. Some fuel properties of BD+GTBEs, B20 fuel, and reference diesel were determined and presented in Table 1. As seen in Table 1, using glycerol ethers by 2 vol.\% ratio caused no significant differences in determined fuel properties. The addition of glycerol ethers led to a slight decrease in fuel density. Due to low glycerol ethers concentration, no changes in the cold flow of properties of test fuels were observed. Also, because of the low boiling temperature of glycerol ethers the distillation temperature (T10) of the BD+GTBEs decreased.

Engine performance and emission tests were performed on a single-cylinder four-stroke research diesel engine. This engine has a stroke volume of $661 \mathrm{~cm}^{3}$ and a compression ratio of $17.5 / 1$. The test engine fitted with the mechanical fuel injection system with an injection pressure of 200 bar and injection timing of $23 \mathrm{CA}$ bTDC. At full engine load and a speed of $1500 \mathrm{rpm}$, the maximum brake power output of the engine is $3.5 \mathrm{~kW}$. Further general specifications for the test engine were presented in Table 2. The engine was connected to a watercooled Eddy current dynamometer (AG series, Model: AG10) to measure engine torque. Dynamometer load was adjusted by changing DC current that is applied to the stator casing to generates a magnetic field and DC current was set by the load button. The external engine cooling system was used to decrease parasitic loads without influencing the engine load conditions. Each test fuels were supplied to the engine by separate fuel tanks.

The engine tests were performed at a fixed speed of $1500 \mathrm{rpm}$ and at $3 \mathrm{~kg}, 6 \mathrm{~kg}, 9 \mathrm{~kg}$, and $12 \mathrm{~kg}$ dynamometer loads which corresponding to 5.5 $\mathrm{Nm}, 10.9 \mathrm{Nm}, 16.3 \mathrm{Nm}$, and $21.8 \mathrm{Nm}$ engine brake torque, respectively. These selected test conditions resulted in equal brake power output at the same test condition for each fuel used. The test engine was started with diesel fuel and operated at idle for 20 minutes in order to warm cylinder walls, lubricant oil, and engine coolant, 


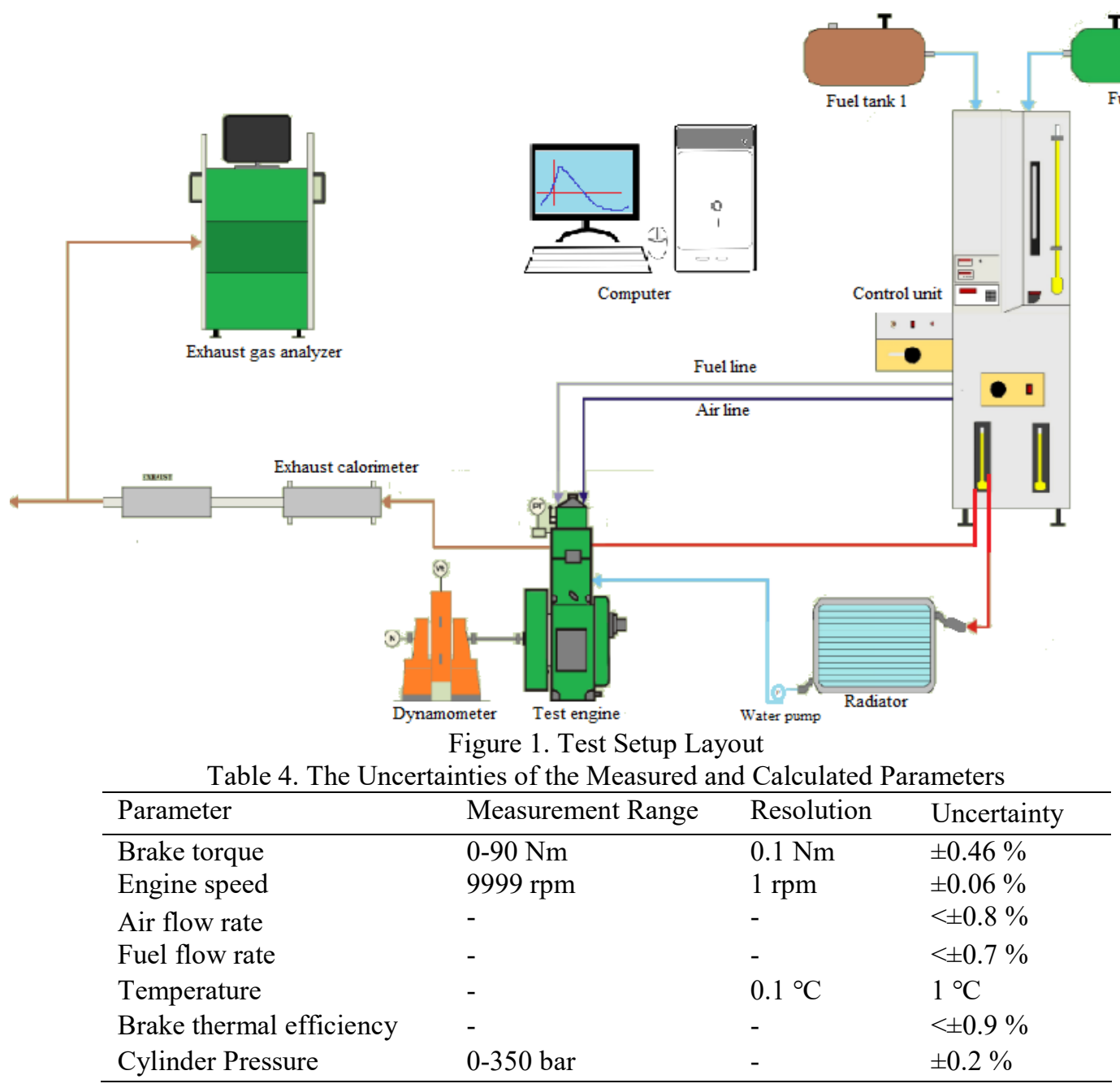

so the measurement conditions were possible. Then, engine speed, engine load, fuel flow rate, induction air flow rate, exhaust temperature, ambient air temperature, ambient air relative humidity, engine coolant temperature was recorded at each test point and test fuel use. Exhaust emissions such as carbon monoxide (CO), hydrocarbon ( $\mathrm{HC}$ ), and nitrogen oxides $(\mathrm{NO})$ were measured with a YT 5003 model exhaust gas analyzer of KTEST. Technical specifications such as measurement range, resolution and accuracy of the exhaust gas analyzer are given in Table 3. All readings were taken under stable operating conditions with three readings and the averaged values were used for calculations. A piezoelectric pressure transducer (PCB Piezotronics, Range 5000 psi. with low noise cable) and a shaft encoder (Kubler-Germany, speed 5500 rpm with TDC pulse) was used to capture cylinder pressure with the resolution of $1 \mathrm{CA}$. The cylinder pressure data were recorded for 100 consecutive cycles and then averaged so that eliminate the effect of cycle-cycle variations. In figure 1 , the experimental layout was illustrated and in Table 4 uncertainties of the measured and calculated parameters were presented.

\section{Results and Discussions}

Since each fuel was tested at the same engine speed and brake engine torque, test fuels produced the same brake power output at the same test condition. Hence, the comparison of the engine performance is made based on specific fuel consumption (SFC) and thermal efficiency (TE). The variation of specific fuel consumption and thermal efficiency for test fuels is presented in Figure 2. It is noticed that SFC decreases while TE increases with increasing the engine power for both fuels, as expected. This is due to an increase in the amount of injected fuel in the cylinder that enhances engine power. In addition, as increase engine power, the heat loss per cycle through the cylinder wall decreases and this consequently reduces the SFC and increases TE. It can be seen in this figure that BD+GTBEs presented slightly 
higher specific fuel consumption than that of B20 and D. This could be attributed to the lower heating value of glycerol ethers [17]. Additionally, an increase in the ignition delay time due to a low cetane number of glycerol ethers could result in more heat transfer to the cylinder wall, thereby the energy that would be converted to power decreased, leading to higher specific fuel consumption [35]. The abovementioned situation is more evident at low engine power because of longer ignition delay time. It is determined that the addition of 2 vol.\% glycerol ethers in the fuel caused an average increase in SFC by $9.20 \%$ and $2.14 \%$ in comparison with diesel and B20 respectively. Glycerol ethers do not show a significant effect on thermal efficiency when compared to B20. However, it results in an average decrease in TE by $1.79 \%$ with respect to diesel fuel. Although the addition of glycerol ethers reduces the energy content of the final fuel, it does not cause a significant decrease in TE. Besides, BD+GTBEs enhances the combustion at full engine load and presents higher TE than those of B20 and diesel. The reasons for this may be extra oxygen content of the fuel due to the addition of glycerol ethers in the biodiesel. Moreover, the low distillation temperature and fuel borne-oxygen of the glycerol ethers could accelerate the combustion which leads to an improved combustion process [17]. Thus, BD + GTBEs fuel shows slightly higher thermal efficiency than those of B20 and diesel at full engine load.

Figure 3 shows the variation of exhaust gas temperature of test fuels. The exhaust temperature with $\mathrm{BD}+\mathrm{GTBEs}$ is lower than those of B20 and D at all engine power outputs. Besides, an average decrease of $2.24 \%$ and $1.36 \%$ in exhaust temperature was determined with the use of glycerol ethers when compared to diesel and B20, respectively. The decrease in exhaust temperature can be attributed to the lower energy content of BD+GTBEs. Additionally, oxygen contained fuels have a lower $\mathrm{A} / \mathrm{F}$ ratio and the amount of air being inducted in the cylinder does not change significantly depending on fuel type in a diesel engine. Therefore, the energy content of the fuel-air mixture in the cylinder further decreases when glycerol ethers are used, which in turn lower exhaust gas temperature.

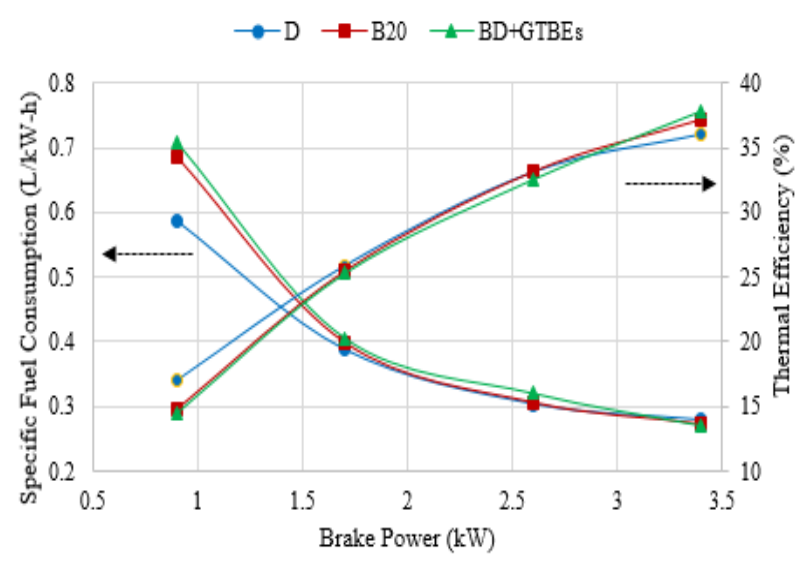

Figure 2. Comparison of Engine Performance for Test Fuels

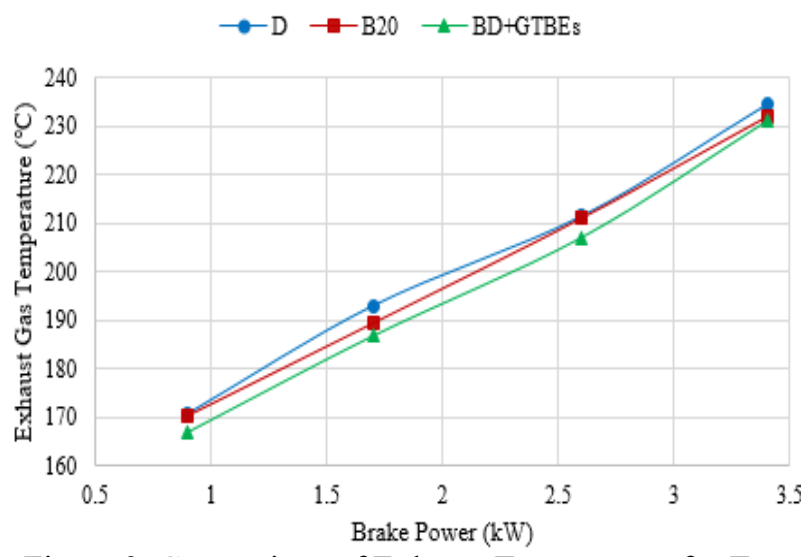

Figure 3. Comparison of Exhaust Temperature for Test Fuels

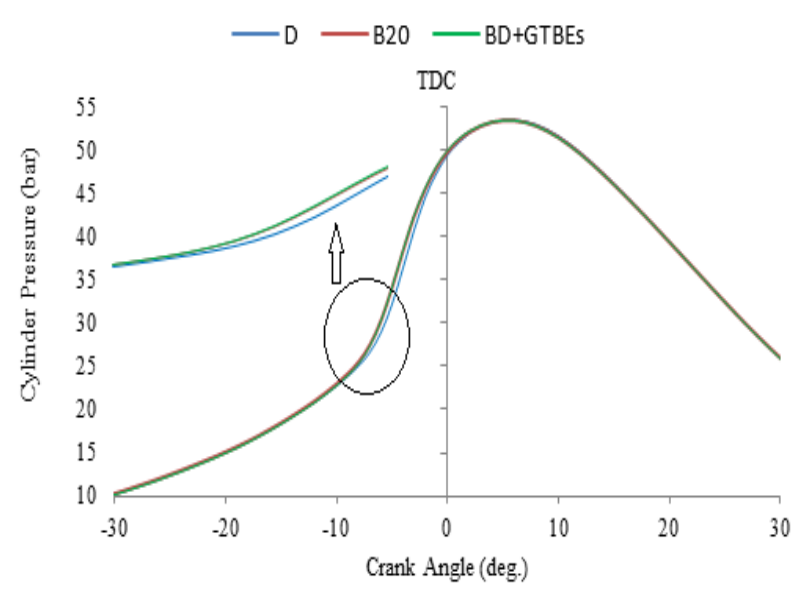

Figure 4. Comparison of Cylinder Pressure at Maximum Brake Power Output for Test Fuels

Figure 4 displays the measured cylinder pressure traces for test fuels at the full engine power output As seen in this figure, no distinguishable difference in the cylinder pressure is observed and the peak cylinder pressure is53.59bar (@6CA),53.53bar (@5 CA), and 53.52 bar (@5 CA), for D,B20, and B20+GTBEs, respectively. This is an expected result since all fuels were tested at the equal brake power output. (Here, it is worth to note 
that the fuel consumption is higher for blended fuels with respect to diesel fuel). A slight difference in the cylinder pressure traces of fuels can be observed before TDC. This region was magnified in the left part of Figure 4. It is noticed that $\mathrm{B} 20$ and $\mathrm{BD}+\mathrm{GTBEs}$ presented rapid premixed combustion with respect to diesel. This may be linked to the low distillation temperature of glycerol ethers and the fast combustion characteristic of oxygenated fuels $[36,37]$.

$\mathrm{CO}$ emissions are incomplete combustion products and hence indicating no full use of chemical energy of any hydrocarbon fuel. The variation of $\mathrm{CO}$ emissions of test fuels is presented in Figure 5. Generally, CO emissions decrease with the use of glycerol ethers when compared to $\mathrm{B} 20$ and it is determined an average decrease in $\mathrm{CO}$ emissions by $2.71 \%$ with the incorporation of glycerol ethers. However, B20 and $\mathrm{BD}+\mathrm{GTBEs}$ produce more $\mathrm{CO}$ emissions overall engine operating points than that of diesel. This increment occurs with an average value of $28.78 \%$ and $31.72 \%$ for BD+GTBEs and B20 compared to diesel fuel. Despite the oxygen content of B20 and BD+GTBEs, the lower heating value of these fuels could reduce the combustion temperature and in turn adversely affect the $\mathrm{CO}$ oxidation process. In addition, another possible reason for high $\mathrm{CO}$ emissions of oxygenated fuels may be the high density and viscosity of B20 and B20+GTBEs. High viscosity and density of the fuel increase the diameter of fuel droplets, leads to higher $\mathrm{CO}$ emissions [38].

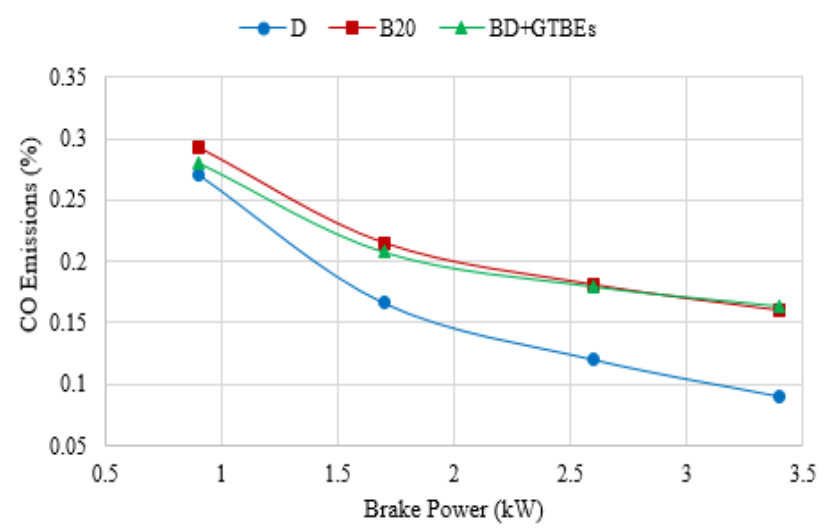

Figure 5. Comparison of CO Emissions for Test Fuels

HC emissions are incomplete combustion species like $\mathrm{CO}$ emissions and cause a significant contribution to air pollution. Figure 6 shows the $\mathrm{HC}$ emissions variation for test fuels.

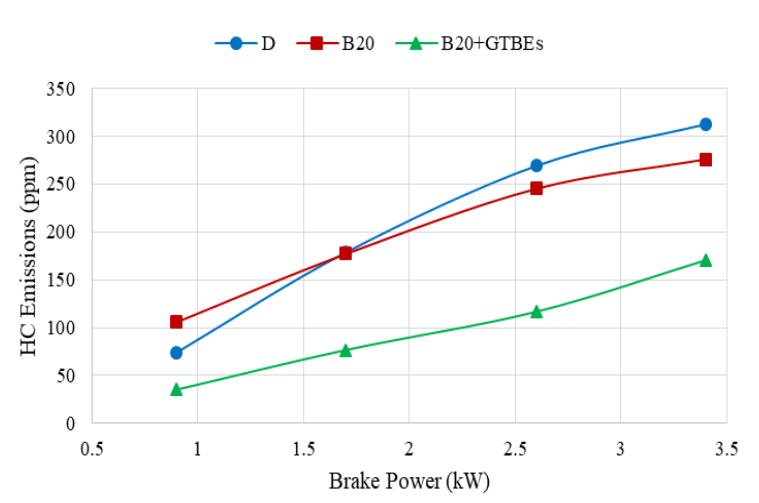

Figure 6. Comparison of HC Emissions for Test Fuels

As seen in this figure the addition of glycerol ethers to biodiesel results in a significant decrease in $\mathrm{HC}$ emissions. BD+GTBEs produces fewer $\mathrm{HC}$ emissions by $50.31 \%$ and $52.32 \%$ averagely compared to B20 and diesel, respectively. Glycerol tert-butyl ethers contain about 39 mol. \% oxygen in chemical structure [17] and the oxygen atoms weakly bonded two carbon atoms [39]. The weakly bonded oxygen atoms in glycerol ethers further aid the fuel oxidation process by it reducing the local fuelrich zones. This results in fewer $\mathrm{HC}$ emissions for BD+GTBEs fuel. Moreover, the lower distillation temperature of glycerol ethers might facilitate the breakdown of the fuel molecules, which improve the fuel combustion. It is important to highlight that the oxidation temperature of $\mathrm{HC}$ is lower than that of $\mathrm{CO}$ oxidation temperature [40], and therefore it can be concluded that the lower heating value of oxygenated fuels has a low impact on $\mathrm{HC}$ emissions than do on $\mathrm{CO}$ emissions.

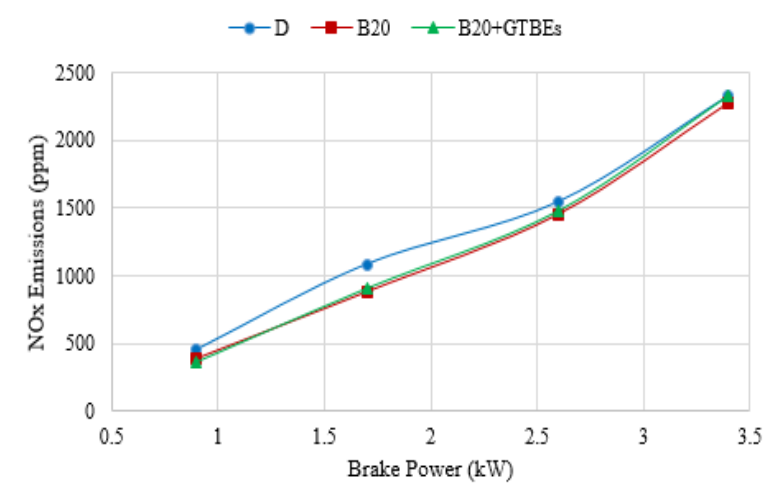

Figure 7. Comparison of $\mathrm{NO}_{\mathrm{X}}$ Emissions for Test Fuels $\mathrm{NO}_{\mathrm{X}}$ emissions are the most undesirable emissions emitted from the exhaust and precautions that are taken to control $\mathrm{NO}_{\mathrm{X}}$ emissions generally lead to an increase in $\mathrm{CO}$, $\mathrm{HC}$ and PM emissions. The effect of test fuels on $\mathrm{NO}_{\mathrm{X}}$ emissions at the various power output is presented in Figure 7. $\mathrm{NO}_{\mathrm{X}}$ emissions of all test 
fuel increase as engine power increase because of enhancing combustion temperature depending on an increase in injected fuel amount [41]. However, as can be noticed in the $\mathrm{NO}_{\mathrm{X}}$ figure, oxygenated fuels generate a lower level of $\mathrm{NO}_{\mathrm{X}}$ emissions compared to diesel fuel. BD+GTBEs and B20 yielded an average reduction in $\mathrm{NO}_{\mathrm{X}}$ emissions by $6.10 \%$ and $7.74 \%$, respectively, compared to diesel fuel. The main reason for this reduction is the low combustion temperature due to the low energy content of biodiesel and glycerol ethers. But at the same time, $\mathrm{BD}+\mathrm{GTBEs}$ produced more $\mathrm{NO}_{\mathrm{X}}$ emissions than that of B20, depend on increasing oxygen concentration due to the addition of glycerol ethers. Even so, BD+GTBEs and B20 emitted fewer $\mathrm{NO}_{\mathrm{X}}$ emissions than that of diesel fuel thanks to fastburn combustion characteristics of the oxygenated fuels.

\section{Conclusion}

In this experimental study, tert-butyl glycerol ethers were synthesized via the etherification reaction of glycerol with tert-butyl alcohol in the presence of Amberlyst-15 as a catalyst and synthesized glycerol ethers were added to a diesel-biodiesel blended fuel to investigate the effect of glycerol ethers on engine performance and exhaust emissions of a diesel engine. Since the heating value of glycerol ethers was lower than that of diesel fuel BD+GTBEs caused an increase in specific fuel consumption and a decrease in thermal efficiency when compared to diesel fuel. The addition of glycerol ethers in the biodiesel-diesel blend reduced $\mathrm{HC}$ and $\mathrm{NO}_{\mathrm{X}}$ emissions while increased $\mathrm{CO}$ emissions, according to diesel. However, the results of this study indicated the possibility to use glycerol ethers at a concentration of 2 vol. \% in a dieselbiodiesel blend without any significant influence on fuel properties, engine performance, and exhaust emissions compared to B20. In addition, this study proves that excess glycerol originated from biodiesel production could be turned into oxygenated fuel and could be used as a fuel additive in diesel engines. It is evident that by evaluating excess glycerol in fuel additive production, environmental pollution caused by excess glycerol will be prevented and it can contribute to a growing share of the amount of renewable fuel used in internal combustion engines.

It is recommended to conduct an economic analysis on glycerol ethers use. Because of the high knock resistance of glycerol tert-butyl ethers, they can also be used as a fuel additive to gasoline. Therefore, the usability of glycerol ethers as an octane booster or oxygenated blending component for gasoline should be investigated in future studies.

\section{Acknowledgments}

This study was supported by the Project Management Office of Ondokuz Mayis University (Project number: PYO.MUH.1904.19.016). Abdülvahap ÇAKMAK has been awarded a doctoral scholarship by the Scientific and Technical Research Council of Turkey (TUBITAKBIDEB: 2211-C). The authors thank Mr. Fatih BILGIN who is the director of the fuel test and analysis laboratory of "Samsun Akaryakit Dağıtım A.Ş." for his technical support.

\section{References}

1. British Petroleum., "BP Energy Outlook 2019", 2019.

2. Singh, S. P., Singh, D., "Biodiesel production through the use of different sources and characterization of oils and their esters as the substitute of diesel: A review", Renew. Sustain. Energy Rev., 14, 200-216, 2010.

3. 1-Zuhair, S., "Production of biodiesel: possibilities and challenges", Biofuels, Bioprod. Biorefining, 1, 57-66, 2007.

4. OECD/FAO, "OECD-FAO Agricultural Outlook 2018-2027", 2018.

5. IEA, "Key World Energy Statistics 2018", 2018.

6. OECD/FAO, "OECD Agriculture statistics (database)", 2018.

7. Noureddini, H., Dailey, W R., and Hunt, B. A.,"Production of ethers of glycerol from crude glycerol - The by-product of biodiesel production", Pap. Biomater., 18, 1-14, 1998.

8. Rahmat, N., Abdullah, A. Z., Mohamed, A. R., "Recent progress on innovative and potential technologies for glycerol transformation into fuel additives: A critical review", Renew. Sustain. Energy Rev., 14, 9871000, 2010.

9. Cornejo, A., Barrio, I., Campoy, M., 
Lázaro, J., Navarrete, B., "Oxygenated fuel additives from glycerol valorization. main production pathways and effects on fuel properties and engine performance: A critical review", Renewable and Sustainable Energy Reviews, 79, 1400-1413, 2017.

10. Serafim, H., Fonseca, I. M., Ramos, A. M., Vital, J., Castanheiro, J. E., "Valorization of glycerol into fuel additives over zeolites as catalysts", Chemical engineering journal, 178, 291-296, 2011.

11. Karinen, R. S., Krause, A. O. I., "New biocomponents from glycerol", Appl. Catal. A Gen., 306, 128-133, 2006.

12. Klepápová, K., Mravec, D., Hajekova, E., Bajus, M., "Etherification of glycerol", Pet. Coal, 45, 1-2, 2003.

13. Klepáčová, K., Mravec, D., Bajus, M., "tert-Butylation of glycerol catalysed by ionexchange resins", Appl. Catal. A Gen., 294, 141-147, 2005.

14. González, M. D., Cesteros, Y., Llorca, J., Salagre, P., "Boosted selectivity toward high glycerol tertiary butyl ethers by microwaveassisted sulfonic acid-functionalization of SBA15 and beta zeolite", Journal of catalysis, 290, 202-209, 2012.

15. Ozbay, N., Oktar, N., Dogu, G., Dogu, T.," Conversion of Biodiesel By-Product Glycerol to Fuel Ethers over Different Solid Acid Catalysts", Int. J. Chem. React. Eng., 8, 2010.

16. Beatrice, C., Di Blasio, G., Lazzaro, M., Cannilla, C., Bonura, G., Frusteri, F., Asdrubali, F., Baldinelli, G., Presciutti, A.,Fantozzi, F., Bidini, G., "Technologies for energetic exploitation of biodiesel chain derived glycerol: Oxy-fuels production by catalytic conversion", Applied energy, 102, 63-71, 2013.

17. Beatrice, C., Di Blasio, G., Guido, C., Cannilla, C., Bonura, G., Frusteri, F., "Mixture of glycerol ethers as diesel bio-derivable oxyfuel: Impact on combustion and emissions of an automotive engine combustion system", Appl. Energy, 132, 236-247, 2014.

18. Çakmak, A., Özcan, H., "Benzin için oksijenli yakıt katkıları", Politeknik Dergisi, 21, 831-840, 2018.

19. Chang, J.-S., Chen, D.H., "Optimization on the etherification of glycerol with tert-butyl alcohol", J. Taiwan Inst. Chem., Eng., 42, 760767, 2011.
20. Frusteri, F., Arena, F., Bonura, G., Cannilla, C., Spadaro, L., Di Blasi, O., "Catalytic etherification of glycerol by tert-butyl alcohol to produce oxygenated additives for diesel fuel", Appl. Catal. A Gen., 367, 77-83, 2009.

21. Kiatkittipong, W., Intaracharoen, P., Laosiripojana, N., Chaisuk, C., Praserthdam, P., Assabumrungrat, S., "Glycerol ethers synthesis from glycerol etherification with tert-butyl alcohol in reactive distillation", Comput. Chem. Eng., 35, 2034-2043, 2011.

22. Klepáčová, K., Mravec, D., Bajus, M., "Etherification of glycerol with tert-butyl alcohol catalysed by ion-exchange resins", Chem. Pap., 60, 224-230, 2006.

23. Liu, J., Zhang, Z., Zhang, P., Yang, B., "On the kinetics of multiphase etherification of glycerol with isobutene", Chemical Engineering Journal, 375, 122037, 2019.

24. Ozbay, N., Oktar, N., Dogu, G., "Dogu, T. Effects of Sorption Enhancement and Isobutene Formation on Etherification of Glycerol with tert -Butyl Alcohol in a Flow Reactor", Ind. Eng. Chem. Res., 51, 8788-8795, 2012.

25. Ozbay, N., Oktar, N., Dogu, G., Dogu, T., "Activity Comparison of Different Solid Acid Catalysts in Etherification of Glycerol with tert-Butyl Alcohol in Flow and Batch Reactors", Top. Catal., 56, 1790-1803, 2013.

26. Bozkurt, Ö. D., Bağlar, N., Çelebi, S., Uzun, A., "Assessment of acid strength in sodium-exchanged resin catalysts: Consequences on glycerol etherification with isobutene in batch and flow reactors", Molecular Catalysis, 466, 1-12, 2019.

27. Paula M. Veiga, Cláudia O. Veloso, Ayres G. Dias, C. A. H., "Identification of Ethyl and t-Butyl Glyceryl Ethers Using Gas Chromatography Coupled with Mass Spectrometry", J. Brazilian Chem. Soc,. 29, 1328-1335, 2018.

28. Viswanadham, N., Saxena, S. K., "Etherification of glycerol for improved production of oxygenates", Fuel, 103, 980-986, 2013.

29. Frusteri, F., Cannilla, C., Bonura, G., Spadaro, L., Mezzapica, A., Beatrice, C., Di Blasio, G., Guido, C., "Glycerol Ethers Production and Engine Performance with Diesel/Ethers Blend", Top. Catal., 56, 378-383, 
2013.

30. Beatrice, C., Di Blasio, G., Lazzaro, M., Mancaruso, E., Marialto, R., Sequino, L., Vaglieco, B. M., "Investigation of the combustion in both metal and optical diesel engines using high-glycerol ethers/diesel blends", Int. J. Engine Res., 16, 38-51, 2015.

31. Özbay, N., "Gliserin Eterlerinin Sentezi ve Reaksiyon Kinetiğinin İncelenmesi", Doktora Tezi, Gazi Üniversitesi, Fen Bilimleri Enstitüsü, 54, Ankara., 2013.

32. Vlad, E., Bildea, C. S., Bozga, G., "Design and Control of Glycerol-tert-Butyl Alcohol Etherification Process", Sci. World J., 2012, 2012.

33. Spooner-Wyman, J. K., Appleby, D. B., Yost, D. M., "Evaluation of Di-Butoxy Glycerol (DBG) for Use As a Diesel Fuel Blend Component", SAE Tech. Pap., No. 2003-0, 2003.

34. Gülüm, M., Bilgin, A., Çakmak, A., "Comparison of optimum reaction parameters of corn oil biodiesels produced by using sodium hydroxide $(\mathrm{NaOH})$ and potassium hydroxide ( $\mathrm{KOH}$ )", J. Fac. Eng. Archit. Gazi Univ., 30, 503-511, 2015.

35. Yilmaz, N., Atmanli, A., Vigil, F. M., "Quaternary blends of diesel, biodiesel, higher alcohols and vegetable oil in a compression ignition engine", Fuel, 212, 462-469, 2018.

36. Emiroğlu, A. O., Şen, M., "Combustion, performance and exhaust emission characterizations of a diesel engine operating with a ternary blend (alcohol-biodiesel-diesel fuel)", Appl. Therm. Eng., 133, 371-380, 2018.

37. Özcan, H., Çakmak, A., "Comparative exergy analysis of oxygenated fuel additives in a spark-ignition (SI) engine", Int. J. Automot. Eng. Technol., 7, 124-133, 2018.

38. Atmanli, A., Ileri, E., Yilmaz, N., "Optimization of diesel-butanol-vegetable oil blend ratios based on engine operating parameters", Energy 96, 569-580, 2016.

39. Kaul, S., Behera, B., Negi, M. S., Porwal, J., Kanojia, P., Tripathi, D., Gupta, P., Bangwal, D., "Efficacy of a bio-additive on the exhaust emissions of petrodiesel", Biomass Convers. Biorefinery, 5, 387-395, 2015.

40. Heywood, J. B., "Internal combustion engine fundamentals", McGraw Hill International Editions, 1988.

41. Behçet, R., Çakmak, A., The Effects on
Engine Performance And Emissions of Fish Oil Methyl Ester Blends Used As Fuel in A Diesel Engine", $6^{\text {th }} \quad$ International Advanced Technologies Symposium (IATS'11), 16-18 May 2011, Elazı ̆̆, Turkey 161-165, 2011. 